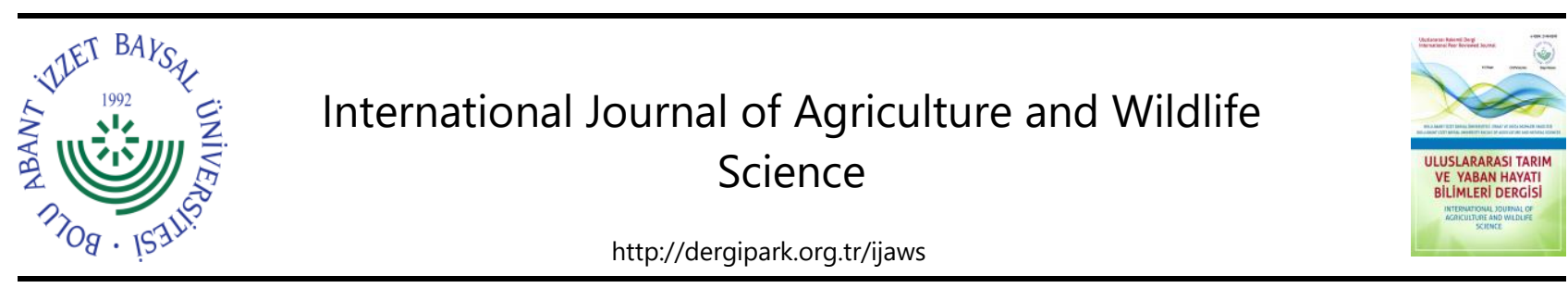

Research Article

\title{
Response of Some Important Olive Cultivars against Wilt Disease Caused by Verticillium dahliae Kleb.
}

\author{
Furkan Coşkun (D), Yaşar Alptekin* \\ Department Plant Protection, Faculty of Agriculture, Kahramanmaras Sutcu Imam University, Kahramanmaras, Turkey
}

Received: 21.05.2021

Accepted: 04.10.2021

Keywords:
Olive, Olea europaea, $\quad$.
dahliae, disease severity

dahliae, disease severity
${ }^{*}$ Corresponding author alptekin69@ksu.edu.tr

\begin{abstract}
This study was carried out to determine some olive varieties' response to Verticillium dahliae Kleb. widely grown in Kahramanmaraş, Turkey. In an initial study to determine the optimal development of $V$. dahliae isolate at different temperatures, $V$. dahliae isolate exhibited an optimal growth at $20^{\circ} \mathrm{C}$. The optimum growth of an isolate of $V$. dahliae was determined on four different growth mediums. The colony growth rate was not significant on all the tested media. The detached leaves of seven different olive varieties were assayed on PDA if $V$. dahliae isolate was attracted to the leaf exudates leached from leaves in vitro. Detached leaves of Memecik $(26.90 \mathrm{~mm})$ and Kalamata $(26.83 \mathrm{~mm}$ ) varieties did not affect colony diameter of $V$. dahliae compared to Control groups on the 8th day. Detached leaves of Domat variety $(31.30 \mathrm{~mm})$ resulted in the most significant colony growth of the $V$. dahliae isolate on PDA. A cross-section of the stem $(0.5 \mathrm{~cm})$ was removed from the upper parts of the inoculation point by measuring 1,2 and $3 \mathrm{~cm}$ and were planted on the PDA medium to determine the disease severity. Memecik variety displayed the lowest severity of the disease with a rate of 0.44 , followed by the Manzanilla variety with 0.66 compared to the other varieties $(1,2$ and 3 $\mathrm{cm}$ from inoculation point). These results indicated that Memecik was the most tolerant variety in leaf section experiments and stem inoculation treatments. However, Domat was the most susceptible variety according to leaf section experiments and stem inoculation treatments.
\end{abstract}

\section{Bazı Zeytin Çeşitlerinin Solgunluk Hastalığı Etmeni Verticillium dahliae Kleb. Karşı Reaksiyonlarının Belirlenmesi}

\author{
Anahtar kelimeler: \\ Zeytin, Olea europaea, $V$. \\ dahliae, hastalık şiddeti
}

\begin{abstract}
Özet. Bu çalışma, Kahramanmaraş ilinde yaygın olarak yetiştirilen bazı zeytin çeşitlerinin Verticillium dahliae Kleb.'e tepkisini belirlemek amacıyla yapılmışır. $V$. dahliae izolatının farklı sıcaklıklarda optimal gelişimini belirlemek için yapılan ilk çalışmada, $V$. dahliae izolatı $20^{\circ} \mathrm{C}$ de optimal bir büyüme göstermiştir. Dört farkıı besi yerlerinde $V$. dahliae izolatının optimum koloni gelişimi belirlenmiştir. Ortalama koloni gelişiminin, test edilen tüm besi yerlerinde istatistiki olarak önemli olmadığı belirlenmiştir. Farklı zeytin çeşitlerinden elde edilen ve PDA ortamında kenarlara yerleştirilen yaprak kesitlerinden salgılanan bitki özütlerinin $V$. dahliae gelişimini teşvik edip etmediği araştırılmıştır. Memecik ve Kalamata çeşitlerinin yaprak kesitleri $V$. dahliae'nın koloni gelişimini 8. Günde Kontrol gruplarına göre etkilememiştir. PDA besiyerinde $V$. dahliae koloni gelişimi en fazla Domat çeşidi yaprak kesitleri tarafından teşvik edilmiş̧ir. İnokulasyon noktalarının 1, 2, $3 \mathrm{~cm}$ yukarısından elde edilen 0,5 $\mathrm{cm}$ gövde kesitlerinden alınan parçalar hastalığın şiddetini belirlemek için PDA ortamına yerleştirilmiştir. Memecik çeşidi 0,44 ile en düşük hastalık şiddetini gösterirken, onu 0,66 ile Manzanilla çeşidi izlemiştir (1, 2 ve $3 \mathrm{~cm}$ 'de). Bu sonuçlar, Memecik çeşidinin hem yaprak kesiti hem de gövde inokulasyon denemelerinde en toleranslı çeşit olduğu tespit edilmiştir. Bununla birlikte, yaprak kesiti ve gövde inokulasyon denemeleri sonucuna göre Domat en duyarlı çeşit olarak belirlenmiştir.
\end{abstract}




\section{INTRODUCTION}

Olive originated in the triangle between Kahramanmaraş, Hatay and Mardin in Southeastern Anatolia (Eskiyörük, 2016) finds the ideal conditions for growth in the Mediterranean climate zone (Fraga et al., 2020). The major of the worldwide olive production comes from the countries in the Mediterranean basin, and it has a significant place in the Turkish economy. Olive is Olea europeae subsp. sativa subspecies of Olea europeae L. species in Oleaceae family. One hundred olive varieties are grown in Turkey. Thus, olive cultivation in Turkey has immense diversity, including wild olive forms and local olive varieties (Erilmez and Erkan, 2016).

Several diseases negatively affect the yield and quality of oil cultivation. Verticillium wilt of olive caused by $V$. dahliae Kleb. is the most important disease that affect fruit trees. Since the disease agent has a broad host spectrum and lives in soil for years without a host, it is difficult to control it chemically and with the other control measures. Resistant olive cultivars to these diseases is effective way of the control (López-Escudero et al., 2011).

The most typical Verticillium wilt symptom is the withering of the offshoots and branches of the trees from the end towards the stem. Furthermore, the branches, shoots and foliage lose their greenish hue and turn into brown. Stem bark turns into violet, and the change of colour expands to the whole tree. When cross-sections are taken from the tree with the symptoms mentioned above, it could be observed that the xylem had turned to dark brown colouration (Agrios, 2005). In olive trees, $V$. dahliae results in two different types of symptoms that could be defined as acute wilt (apoplexy) and chronicle wilt (Bakhouchea et al., 2018). Acute wilt generally develops from late winter to early spring. Shoots and branches rapidly wither and die. As a result, the whole tree could die (Tsror et al., 2011). On the other hand, chronic wilt is generally characterized by the necrosis of flowers. The leaves on diseased branches turn into a dull green colour, and the leaves finally are defoliated before winter. These symptoms are followed by acute wilt symptoms in spring (Tsror et al., 2011).

According to Navas-Cortés (2008), microsclerotia of the pathogen found in the upper layers of the soil spread due to factors such as cultural processes, irrigation and wind. It was reported that the disease amount in the soil increases with the defoliation and non-defoliation of the diseased olive tree. According to García-Cabello et al. (2012), the pathogen could spread to short or long distances due to surface irrigation. Fradin et al. (2006) stated that the pathogen could spread using infected plant material such as infected rootstocks, bulbs and tubers. Contaminated material use in nurseries causes transportation of the pathogen to new locations (Hantal, 2008).

Tolerant olive rootstocks and varieties play a significant role in the control of the disease. Although intensive studies were conducted in certain other countries on disease-tolerant rootstock and varieties, there are not enough studies in Turkey that scrutinized the tolerance of economically cultivated varieties and rootstock. Thus, it is crucial to determine wilt disease-tolerant olive varieties cultivated in Kahramanmaraş province.

\section{MATERIAL AND METHOD}

\section{Plant Materials and Pathogen Isolate}

Verticillium dahliae isolate was obtained from the samples collected during the field survey conducted in olive orchards in Kahramanmaraş Region. Certified olive saplings obtained from Olive Research Institute- Bornova, İmir. Ayvalık, Gemlik, Memecik, Domat, Kalamata, Manzanilla, Erkence varieties were used in this study. All the olive saplings were $1.5-2$ years old and displayed homogenous growth.

\section{Development of the Isolate in PDA Medium under Different Temperatures}

The optimum growth rate was determined by using $7 \mathrm{~mm}$ diameter discs obtained from $V$. dahliae isolate cultured in PDA (Potato Dextrose Agar) for two weeks were planted in PDA medium. Five petri dishes per temperature were placed in incubators set for $5,10,15,20$ and $25^{\circ} \mathrm{C}$ in the dark. The growth of the isolates under these temperatures was monitored for 10 days by measuring the colony diameters. Thus, optimum growth temperatures or temperature demands of the isolate were assessed.

\section{Growth of the Isolate in a Different Medium}

The optimum growth rate of the isolate was evaluated by using $7 \mathrm{~mm}$ diameter discs obtained from $V$. dahliae isolate cultured in PDA for two weeks were planted in PDA, SDA (Saboroud Dextrose Agar), WA (Water Agar) and CZA (Czapek-Dox Agar) media, and placed in $24^{\circ} \mathrm{C}$ incubator. The experiment was designed as completely randomized plots with four replicates. The growth of the isolates in these media was monitored for 10 days by measuring the colony diameters. Thus, the optimum growing medium for the isolate was assessed. 


\section{The Reaction of the Isolate to Leaves of Different Olive Varieties on PDA Medium}

Seven $\mathrm{mm}$ diameter discs obtained from $V$. dahliae isolate cultured in PDA for two weeks were planted in PDA medium in $9 \mathrm{~mm}$ in diameter Petri dishes. Leaves obtained from 7 different olive varieties (Ayvalık, Gemlik, Memecik, Domat, Kalamata, Manzanilla, Erkence) were surface disinfected for 2 minutes using $96 \%$ alcohol. The leaves were then rinsed with distilled water three times and left for 15 minutes on sterile blotting paper. Approximately $1 \mathrm{~cm}^{2}$ piece was incised using a sterile scalpel and planted in four corners of the medium at equal distances to the disc. Petri dishes were left for growth in the $24^{\circ} \mathrm{C}$ incubator and assessed daily for eight days for colony growth. Finally, the reaction of the isolate to leaf incisions obtained from different olive varieties was evaluated.

\section{In vivo Reaction of Different Olive Varieties to Verticillium dahliae}

Ayvalık, Gemlik, Erkence, Manzanilla, Memecik, Kalamata, Domat olive varieties were tested for their reaction to $V$. dahliae isolate in a growth chamber 8-hour dark and 16-hour light conditions. The isolates obtained in the survey were grow in PDA medium for one week, and the culture was cut in strips and place in a 5-ml sterile syringe. The fungal culture was ejaculated through the needle once. The macerated fungal culture was loaded again by a 5-ml the syringe. The stem inoculation technique developed by Pennisi et al. (1993) was modified and used in this study. Three equal slits $(1 \mathrm{~cm}$ long) in the stem of sampling $5 \mathrm{~cm}$ from the soil surface were prepared just before inoculation. The inoculum, $0.5 \mathrm{ml}\left(450 \mathrm{cfu} \mathrm{mL}^{-1}\right)$ of the culture mix, was unloaded into the slit with the syringe and inoculated stem section was sealed with a parafilm (modified from Schmitthenner and Bhat, (1994)). Inoculated plants were left under controlled conditions for 12 weeks. The $0.5 \mathrm{~cm}$ stem cuts were taken from 1,2 , $3 \mathrm{~cm}$ above the inoculation points via a scalpel and were placed on the PDA medium to check the presence of fungal growth. Obtained samples were surface-disinfected for 2 minutes, with $96 \%$ alcohol. These were washed three times with sterile water and left for 15 minutes on blotting paper, and placed onto a PDA medium. The samples were evaluated with a 0-1 scale ( $0: V$. dahliae growth was not observed on PDA, $1: V$. dahliae growth was observed on PDA). Seven olive cultivars with three replicates were used in a completely randomized plot experimental design, and the data was analyzed, and means were separated by Fisher's multiple comparison test (SPSS, 2020).

\section{RESULTS AND DISCUSSION}

Mean colony diameters of $V$. dahliae the isolate in PDA in five different temperature $\left(5,10,15,20,25^{\circ} \mathrm{C}\right)$ were shown in Figure 1.

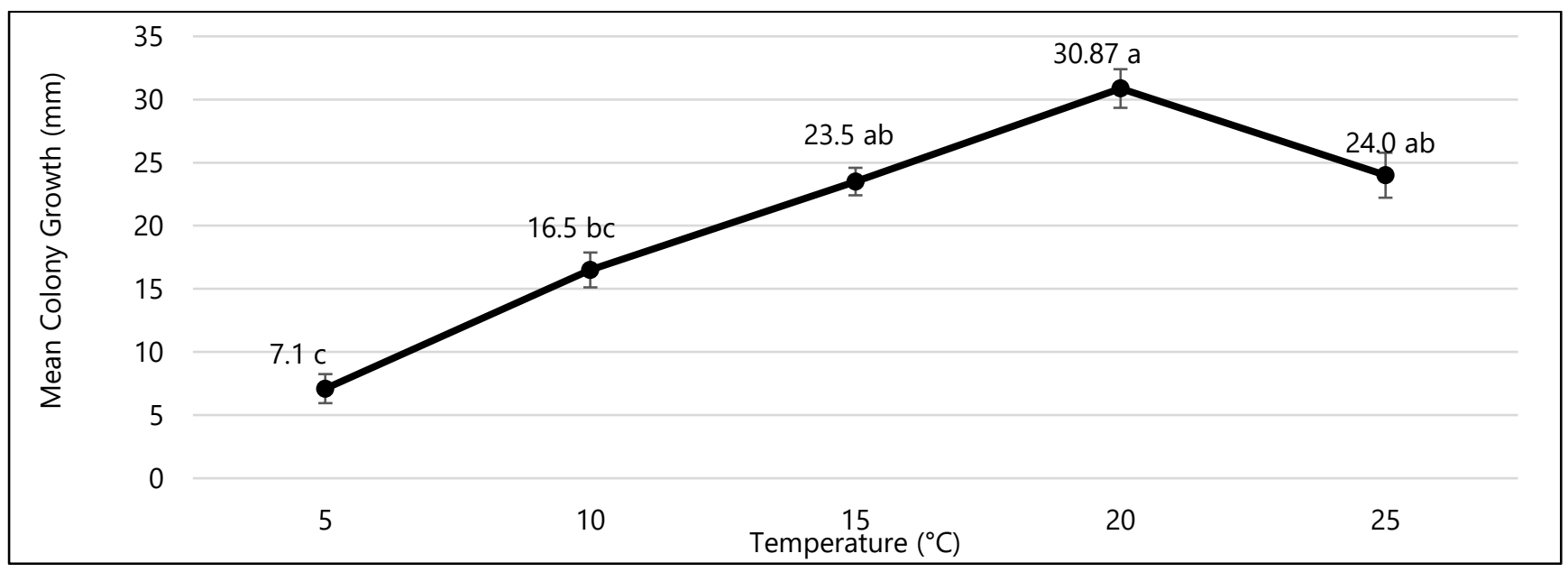

Data followed by different letters above the line indicate significant differences $(P<0.05)$ between treatments.

Figure 1. Mean colony growth of isolate at 10th day under different temperatures obtained from olive orchards in Kahramanmaraş province.

Şekil 1. Kahramanmaraş ili zeytin bahçelerinden elde edilen izolatın 10. günde farklı sıcaklıklarda ortalama koloni gelişimi.

Optimum colony growth was observed at $20^{\circ} \mathrm{C}$ with $30.87 \mathrm{~mm}$, followed by the growth at $25^{\circ} \mathrm{C}$ with $24 \mathrm{~mm}$. Mean colony diameters at $15-25{ }^{\circ} \mathrm{C}$ were not statistically different from each other. Colony growth at $5{ }^{\circ} \mathrm{C}$ was relatively slow with $7.10 \mathrm{~mm}$ followed by $10^{\circ} \mathrm{C}$ with $16.50 \mathrm{~mm}$ (Figure 1). Optimal growth temperatures of isolate and microsclerotia characteristics are essential criteria to differentiate the $V$. dahliae pathotypes (Schnathors and 
Mathre, 1966; Biçici and Kurt, 1998; Onan and Karcılıoglu, 1998; Göre, 2007). Thus, to determine the temperature demand of $V$. dahliae isolate, the isolate was cultured at $5,10,15,20,25^{\circ} \mathrm{C}$. In studies conducted in the Aegean Region and the Eastern Mediterranean Region, isolates have been grouped by $24^{\circ} \mathrm{C}$, and $27^{\circ} \mathrm{C}$. While the optimal temperature of cotton isolates in the Aegean Region is $24^{\circ} \mathrm{C}$ (Saydam, 1976; Onan and Karcılıoğlu, 1998), those that prefer $24^{\circ} \mathrm{C}$ and $27{ }^{\circ} \mathrm{C}$ were found among the Eastern Mediterranean isolates (Biçici and Kurt, 1998). In a later study, isolates showing optimal growth at both temperatures were found in the Aegean Region isolates (Göre, 2007). Another study showed that $V$. dahliae barely produced microsclerotia at temperatures over $30^{\circ} \mathrm{C}$ (Liu et al., 2021).

Colony characteristics and growth of $V$. dahliae isolate in the different growth were evaluated and presented in Figure 2.

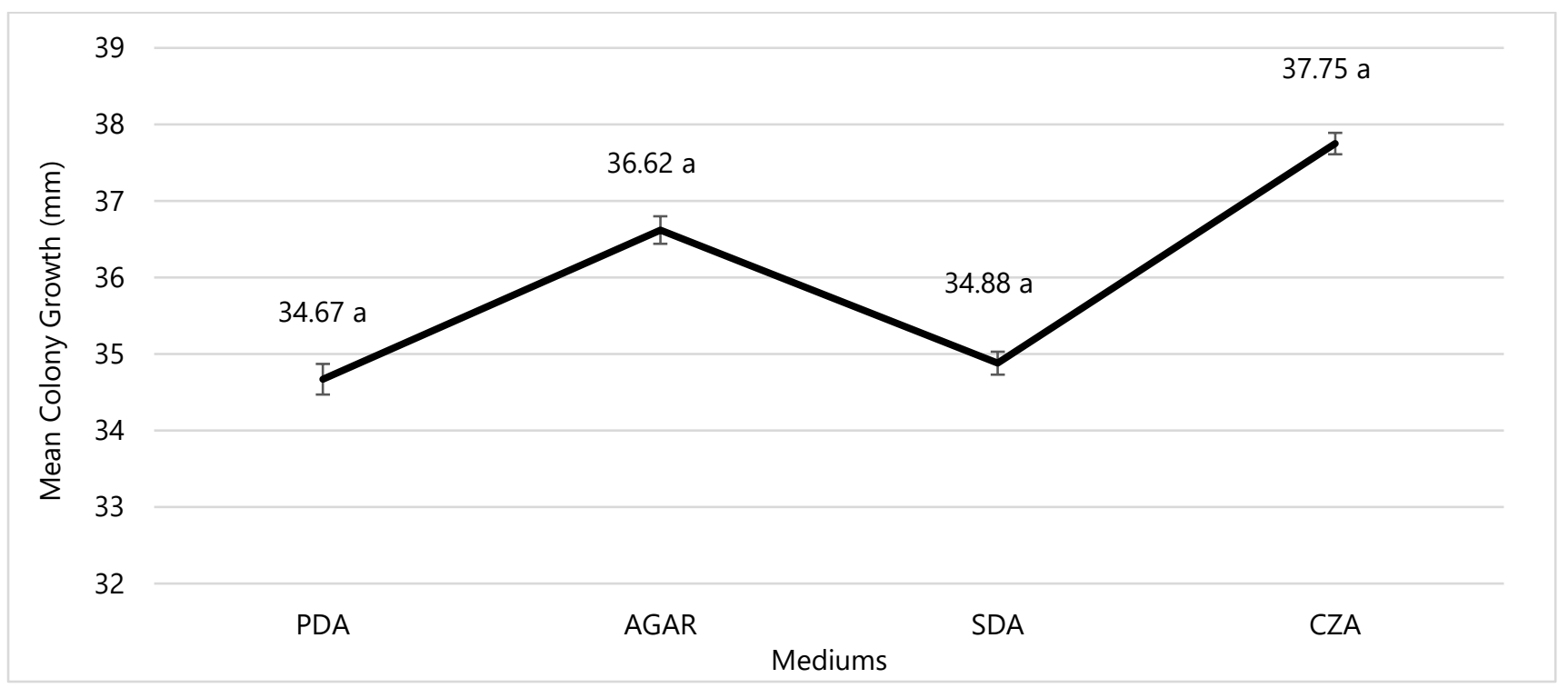

Data followed by different letters above the line indicate significant differences $(P<0.05)$ between treatments.

Figure 2. Mean colony diameters of $V$. dahliae isolate on the 10 th day in different mediums.

Şekil 2. Farklı besi yerlerinde V. dahliae izolatının 10. günde ortalama koloni gelişimi.

Verticillium dahliae isolates displayed very similar growth in the different mediums, and growth rate were not statistically different in different growth mediums. As a result, it was observed that there was no difference between the medium preference of $V$. dahliae isolate though the colony growth was better in the CZA medium than the other tested growth mediums (Figure 2). Kabir et al. (2005) showed that NP-10 containing P-3889 and $0.025 \mathrm{~N} \mathrm{NaOH}$ supported the growth and production of $V$. dahliae. According to Goud et al. (2003), V. dahliae was determined to have large microsclerotia and abundant dark hyphae on ethanol agar (EA), while $V$. dahliae was not dark-coloured hyphae or dark mycelium in modified soil extract agar (MSEA), which is a pectate-based agar. Wang et al. (2014) showed that Verticillium albo-atrum produced optimal mycelial growth in PLYA (Prune Lactose Yeast Extract Agar) medium. In another study, the highest growth rate of Verticillium alfalfae was obtained in the Czapek agar medium (Li et al., 2021).

Table 1. Mean colony diameters of the isolate were determined on the 8th day based on their growth on PDA medium in which leaf incisions obtained from different olive varieties were placed to the edges.

Çizelge 1. Farklı zeytin çeşitlerinden elde edilen yaprak kesilerinin kenarlara yerleştirildiği PDA besiyerinde izolatın 8 . Günde ortalama koloni çapları.

\begin{tabular}{ll}
\hline Olive Varieties & Mean Colony Growth $(\mathbf{m m})^{*}$ \\
\hline Manzanilla & $27.83 \pm 0.50 \mathrm{bc}$ \\
Memecik & $26.90 \pm 0.42 \mathrm{c}$ \\
Erkence & $28.30 \pm 0.25 \mathrm{bc}$ \\
Gemlik & $29.73 \pm 0.28 \mathrm{ab}$ \\
Ayvalık & $28.00 \pm 0.26 \mathrm{bc}$ \\
Kalamata & $26.83 \pm 0.15 \mathrm{c}$ \\
Domat & $31.30 \pm 0.35 \mathrm{a}$ \\
Control & $27.26 \pm 0.29 \mathrm{c}$ \\
\hline
\end{tabular}

* There is no statistical difference between the values marked with identical letters $(P<0.05)$. 
Memecik and Kalamata olive varieties did not show any significant differences in colony growth than the control. Mean colony diameters of Kalamata and Memecik olive varieties varied from 26.83 and $26.90 \mathrm{~mm}$, respectively. Manzanilla, Erkence and Ayvalık olive varieties displayed and slightly higher colony growth than that of the control group. Gemlik olive variety performed the best colony growth in diameter, followed by Domat olive variety. Their colony diameters varied from 29.73 and $31.30 \mathrm{~mm}$. Leaf exudates from the Domat variety were attracted more by the $V$. dahliae isolate than the other olive varieties. Kalamata and Memecik varieties displayed the lowest colony growth, and hence, they were more tolerant when compared to other varieties (Table 1). Exudates or components of exudates specifically influenced pathogen growth and production (Wu et al., 2010). In the study by Liu et al. (2009), mycelia growth of $V$. dahliae was inhibited by root exudate of grafted eggplants, whereas root exudate of ungrafted eggplants increased mycelium growth. Wang (2010) showed the effect of root exudate of cucumber plant on the density of Fusarium oxysporum f. sp. cucumerinum (Foc), reported that root exudates from a resistant cultivar reduced foc's survival time. According to Zhu et al. (2011), root exudates from resistant varieties prevented $V$. dahliae growth, but the susceptible variety encouraged it, and the root exudates' influence decreased incrementally. Development of $V$. dahliae in culture medium supported with the root exudate of Potato onion was significantly suppressed (Li et al., 2018).

The results obtained regarding the $V$. dahliae growth in woody plant tissues on PDA obtained from $1,2,3 \mathrm{~cm}$ above inoculation points are given in Table 2.

Table 2. Presence of $V$. dahliae on $0.5 \mathrm{~cm}$ stem sections on PDA obtained from 1, 2, $3 \mathrm{~cm}$ above inoculation points. Çizelge 2. Inokulasyon noktalarının 1, 2, $3 \mathrm{~cm}$ yukarısından elde edilen 0,5 cm gövde kesitlerinin PDA'daki V. dahliae varlığı.

\begin{tabular}{llll}
\hline $\begin{array}{l}\text { Olive } \\
\text { Varieties }\end{array}$ & $\begin{array}{l}\text { Disease Severity (based on } \mathbf{0 - 1} \\
\text { scale) } \mathbf{1} \mathbf{~ c m}{ }^{*}\end{array}$ & $\begin{array}{l}\text { Disease Severity (based on } \mathbf{0 - 1} \\
\text { scale) } \mathbf{2} \mathbf{~ c m}\end{array}$ & $\begin{array}{l}\text { Disease Severity (based on } \mathbf{0 - 1} \\
\text { scale) } \mathbf{3} \mathbf{~ c m}{ }^{* *}\end{array}$ \\
\hline Manzanilla & $0.66 \pm 0.57 \mathrm{bc}$ & $0.66 \pm 0.57 \mathrm{bc}$ & $0.66 \pm 0.57 \mathrm{a}$ \\
Memecik & $0.44 \pm 0.52 \mathrm{c}$ & $0.44 \pm 0.52 \mathrm{c}$ & $0.44 \pm 0.52 \mathrm{~b}$ \\
Erkence & $0.88 \pm 0.33 \mathrm{ab}$ & $1.0 \pm 0 \mathrm{a}$ & $1.0 \pm 0 \mathrm{a}$ \\
Gemlik & $0.88 \pm 0.33 \mathrm{ab}$ & $1.0 \pm 0 \mathrm{a}$ & $1.0 \pm 0 \mathrm{a}$ \\
Ayvalık & $0.88 \pm 0.33 \mathrm{ab}$ & $1.0 \pm 0 \mathrm{a}$ & $1.0 \pm 0 \mathrm{a}$ \\
Kalamata & $1.0 \pm 0 \mathrm{a}$ & $0.88 \pm 0.33 \mathrm{ab}$ & $0.88 \pm 0.33 \mathrm{a}$ \\
Domat & $1.0 \pm 0 \mathrm{a}$ & $1.0 \pm 0 \mathrm{a}$ & $1.0 \pm 0 \mathrm{a}$ \\
\hline
\end{tabular}

* There is no statistical difference between the values marked with identical letters $(P<0.05)$.

** There is no statistical difference between the values marked with identical letters $(P<0.01)$.

Verticillium dahliae growth rate on stems of seven different olive varieties were evaluated by sampling $0.5 \mathrm{~cm}$ stem cut 1,2 and $3 \mathrm{~cm}$ from inoculation points and incubating on PDA in a $24 \pm 1{ }^{\circ} \mathrm{C}$. Memecik variety displayed the lowest severity of the disease with a rate of 0.44 compared to the other varieties according to stem cut $1 \mathrm{~cm}$ from inoculation points. Manzanilla variety showed disease severity with a rate of 0.66 . Gemlik, Ayvalık, and Erkence varieties were in the same group and demonstrated a disease severity rate of 0.88 . The highest severity of disease was observed in Domat and Kalamata olive varieties with a rate of 1 on PDA medium (Table 2).

Verticillium dahliae growth in woody plant tissues on PDA obtained from $2 \mathrm{~cm}$ above inoculation points of the stem was statistically analyzed. It was observed that the Memecik variety displayed the lowest severity of the disease with a rate of 0.44 , followed by Manzanilla olive variety with 0.66 disease severity. Kalamata variety showed disease severity with a rate of 0.88 . Gemlik, Ayvalık, Domat, and Erkence varieties displayed the most severe disease with a rate of 1 (Table 2 ).

Verticillium dahliae growth in woody plant tissues on PDA obtained from $3 \mathrm{~cm}$ above inoculation points were as follows. Disease severity on Memecik variety was 0.44 , whereas it was significantly higher on Gemlik, Ayvalık, Domat, Erkence, Manzanilla, and Kalamata olive varieties varied from 0.66 and 1 (Table 2).

Erten (2004), using a virulent pathotype (TI) of $V$. dahliae, investigated the reactions of 51 olive varieties consisting of 46 local and five foreign varieties and four wild clonal rootstocks against the pathogen. Most of the varieties and rootstocks used in the stem inoculation tests were highly sensitive to the pathogen. On the other hand, four local varieties (Dilmit, Erdek Yağlık, Siyah Salamura, and Yün Çelebi) 2 foreign varieties Arbequine and Frantoi) were found resistant to the pathogen, with disease severity not exceeding the $30 \%$ limit. Six local varieties, Gemlik, Belluti, Butko, Samanl, Saurani and Sinop No: 2, one clonal rootstock (D9) and three foreign varieties (Ascolana, Chemlali, Leccinö) were included in the moderately sensitive reactive group. As Erten (2004) stated, all olive varieties we tested were sensitive to the pathogen, except for the Memecik variety. Approximately one year 
after engrafting, the pathogen was inoculated to the rootstock (stem). The prognosis was more progressive in Manzanilla engrafted D9 rootstock than Manzanilla engrafted D36 (Wilhelm and Taylor 1965; Hartmann et al. 1971; Caballero et al. 1980). Erten and Yıldız (2004) determined the sensitivities of 10 different olive varieties to $V$. dahliae cultivated in the Southeastern Anatolia region. In the study, one-year-old saplings were inoculated with a high-virulence $V$. dahliae isolate (VCG1) by injection on reciprocal scars on the stem. Yün Çelebi variety was in the resistant group with $18.25 \%$ and $23.75 \%$ virulence rates after three months and one year, respectively. Initial 12 weeks determined that Halhalı Çelebi variety was in the medium-sensitive group (41.66\%). Two pathotypes of $V$. dahliae were used in another study conducted with Arbequino, Frantoi and Leccino varieties. Arbequine and Leccino varieties were found to be susceptible (E), although Frontio variety was moderately-sensitive (MS) for pathotype that causes defoliation (D). In the experiment conducted with non-defoliating pathotype (ND), Arbeguine, Leccino and Frantoi varieties were found to be sensitive (S), medium-sensitive (MS) and resistant (R), respectively (López-Escudero et al. 2004). In the experiments carried out by grafting susceptible olive varieties with economic importance on some clonal rootstocks and varieties moderately resistant to $V$. dahliae, while the disease was determined at a rate of $91.67 \%$ in control, disease severity values were found between $0 \%$ and $41.67 \%$ in all applications except D-9 + Uslu (disease rate 86.67\%) (Yıldız et al., 2020). Pedro et al. (2021) assessed that the variability in resistance to Verticillium wilt of olive trees in progenies from five crosses: 'Picual' $\times$ 'Frantoio', 'Arbosana' $\times$ 'Koroneiki', 'Sikitita' $\times$ 'Arbosana', 'Arbosana' $\times$ 'Frantoio' and 'Arbosana' $\times$ 'Arbequina' and their respective reciprocal crosses. They indicated no significant differences for any of the assessed parameters when reciprocal crosses were compared.

\section{CONCLUSION}

Verticillium wilt caused by $V$. dahliae is one of the most important diseases encountered in olive cultivation in Turkey, similar to several other crops and other countries. The facts that the disease agent has a wide host range is a soil-borne pathogen, and the lack of a limited number of chemical control methods against it increases the significance of the disease.

The present study indicated that Memecik was the most tolerant olive variety according to the stem inoculation method and detached leaf assay. Thus, it can be suggested that the Memecik variety should be planted in low-land areas with $V$. dahliae contaminated soil or replanted of dead olives in an orchard. Furthermore, Domat was not recommended to plant in possibly contaminated with the pathogen areas since it was the most susceptible variety in this study.

Overall results demonstrated that variety selection is crucial for the control of the disease. Adaptation of these varieties in the region also affects the success of the management of the disease. Several factors such as irrigation method, soil structure, cleanliness of the tools and equipment used, utilization of healthy saplings and the variety of the plants used in interim agriculture affect the development of the disease. Thus, to succeed in managing the disease, all these factors should be meticulously taken into account.

\section{CONFLICT OF INTEREST}

The authors have declared no conflict of interest.

\section{DECLARATION OF AUTHOR CONTRIBUTION}

The authors declare the contribution of the authors is equal.

\section{ACKNOWLEDGMENT}

This study was supported by [Kahramanmaraş Sütçü İmam University, Scientific Research Projects Coordination Unit] under Grant [2013/7-7 YLS].

\section{REFERENCES}

Agrios, G. N. (2005). Plant Pathology. The Fifth Edition, Academic Press, Department of Plant Pathology, University of Florida, USA. 
Bakhouchea, A., Lorenzo-Sanchez, J., Alberto Fernandezguiéerrez, A., \& Segura-Carretero, A. (2015). Trends in chemical characterization of virgin olive oil phenolic profile: an overview and new challenges. Olivae [online], 122, 3-15.

Biçici, M., \& Kurt S. (1998). Etiology, incidence ve prevalence of cotton wilt disease and strains of the wilt pathogen in Çukurova. Proceedings of the World Cotton Research Conference-2. New Frontiers in Cotton Research, Athens, Greece.

Caballero, J. M., Perez Hernandez, J., Blanco-Lopez, M. A., \& Jimenez-Diaz, R. M. (1980). Olive, a new host of Verticillium dahliae in Spain. Proceedings of the $5^{\text {th }}$ Congress of the Mediterranean Phytopathological Union, Patras, Greece.

Erten, L. (2004). Bazı Zeytin Çeşit ve Anaçlarının Verticillium Solgunluğu'na (Verticillium dahliae Kleb.) Duyarlııklarının Belirlenmesi. Doktora Tezi, Ege Üniversitesi Fen Bilimleri Enstitüsü, Bornova, İzmir.

Erten, L., \& Yildiz, M. (2004). Susceptibility of Some Economically Important Olive Cultivars and Clones to Verticillium dahliae Kleb in Turkey. V. International Symposium on Olive Growing, İzmir, Turkey.

Erilmez, S., \& Erkan, S. (2016). The comparison of sensitivity of various methods in the detection of olive tree viruses. The Journal of Turkish Phytopathology, 45(1), 1-12.

Eskiyörük, D. (2016). Antik Çağda Zeytin ve Zeytinyağı: Kilikya Bölgesi Örneği. Journal of Tourism and Gastronomy Studies, 4 (Special issue 1), 228-243.

Fradin, E. F., \& Thomma, B. P. (2006). Physiology and molecular aspects of Verticillium wilt diseases caused by $V$. dahliae and V. albo-atrum. Molecular Plant Pathology, 7(2), 71-86.

Fraga, H., Pinto, J. G., Viola, F., \& Santos, J. A. (2020). Climate change projections for olive yields in the Mediterranean Basin. International Journal of Climatology, 40(2), 769-781.

García-Cabello, S., Pérez-Rodríguez, M., Blanco-López, M. A., \& López-Escudero, F. J. (2012). Distribution of Verticillium dahliae through watering systems in widely irrigated olive growing areas in Andalucia (southern Spain). European Journal of Plant Pathology, 133(4), 877-885.

Goud, J. K. C., Termorshuizen, A. J., \& Gams, W. (2003). Morphology of Verticillium dahliae and V. tricorpus on semi-selective media used for the detection of V. dahliae in soil. Mycological Research, 107(7), 822-830.

Göre, M. E. (2007). Vegetative compatibility and pathogenicity of Verticillium dahliae isolates from the Aegean Region of Turkey. Phytoparasitica, 35(3), 222-231.

Hantal, M. (2008). Güney Marmara bölgesi zeytinliklerinde Verticillium solgunluğunun yaygınlığı ve etmenin patotiplerinin belirlenmesi. Yüksek Lisans Tezi, Ege Üniversitesi Fen Bilimleri Enstitüsü, Bornova, İzmir.

Hartmann, H., Schnathorst W., \& Whisler J. (1971). Oblonga a clonal olive rootstock resistant to Verticillium wilt. California Agriculture, 25(6), 12-15.

Kabir, Z., Bhat, R. G., \& Subbarao, K. (2004). Comparison of media for recovery of Verticillium dahliae from soil. Plant Disease, 88(1), 49-55.

Li, H. Y., Zhou, X. G., \& Wu, F. Z. (2018). Effects of root exudates from potato onion on Verticillium dahliae. Allelopathy Journal, $43(2), 217-222$

Li, F., Matloob, M., Nzabanita, C., \& Li, Y. (2021). Growth, sporulation and germination of Verticillium alfalfae on media. European Journal of Plant Pathology, 161, 383-395.

Liu, N., Zhou, B., Zhao, X., Lu, B., Li, Y., \& Hao, J. (2009). Grafting eggplant onto tomato rootstock to suppress Verticillium dahliae infection: the effect of root exudates. HortScience, 44(7), 2058-2062.

Liu, L., Zhang, Y. D., Zhang, D. D., Zhang, Y. Y., Wang, D., Song, J., Zhang, J., Li, R., Kong, Z. Q., Klosterman, S. J., Dai, X. F., Subbarao, K. V., Zhao, J., \& Chen, J. Y. (2021). Biological characteristics of Verticillium dahliae MAT1-1 and MAT1-2 strains. International Journal of Molecular Sciences, 22(13), 7148.

López-Escudero F. J., Del Río C., Caballero J. M., \& Blanco-López M. A. (2004). Evaluation of olive cultivars for resistance to Verticillium dahliae. European Journal of Plant Pathology, 110(1), 79-85.

López-Escudero, F. J., \& Mercado-Blanco, J. (2011). Verticillium wilt of olive: a case study to implement an integrated strategy to control a soil-borne pathogen. Plant and Soil, 344(1), 1-50.

Navas-Cortés, J. A., Landa, B. B., Mercado-Blanco, J., Trapero-Casas, J. L., Rodríguez-Jurado, D., \& Jiménez-Díaz, R. M. (2008). Spatiotemporal analysis of spread of infections by Verticillium dahliae pathotypes within a high tree density olive orchard in southern Spain. Phytopathology, 98(2), 167-180.

Onan, E., \& Karcılığlu, A. (1998). Pathotypes of Verticillium dahliae from cotton in Aegean Region and review of Verticillium wilt tolerance in Nazilli 84 cotton. Journal of Turkish Phytopathology, 27, 113-120. 
Pedro, V. C., Carlos, T. R., Diego, B. N., Escudero, F. J. L., Ana, G. B. C., \& Díez, C. M. (2021). Assessment of maternal effects and genetic variability in resistance to Verticillium dahliae in olive progenies. Plants, 10(8), 1534

Pennisi, A., Cacciola, O., Magnanodi Sanlio, G. \& Perrotta, G. (1993). Evaluation of the susceptibility of olive cultivars to Verticillium wilt. OEPP/EPPO Bulletin, 23,537-541.

Saydam, C. (1976). Verticillium wilt on different host plants in Turkey. Probleme de Protectia Plantelor, 4, 213-218.

Schmitthenner, A. F., \& Bhat, R. G. (1994). Useful Methods for Studying Phytophthora in the Laboratory. Special circular 143. Ohio Agricultural Research and Development Center, Columbus, OH, USA.

Schnathorst, W. C., \& Mathre, D. E. (1966). Host range and differentiation of a severe form of $V$. albo-atrum in cotton. Phytopathology, 56, 1155-1161.

SPSS. (2020). IBM SPSS Statistics 22.0 for Windows. Armonk, NY.

Tsror, L. (2011). Epidemiology and control of Verticillium wilt on olive. Israel Journal of Plant Sciences, 59(1), 59-69.

Wang, H. L. (2010). Effects of root exudates of cucumber on population of Fusarium oxysporum f.sp. cucumerinum in soil as detected by Realtime PCR. Journal of Shanghai Jiaotong University - Agricultural Science, 1(28), 41-45.

Wang, L. L., Li, F., Riziwangguli, Lang, Y. Y., Patiguli, \& Li, K. M. (2014). Biological characteristics of the pathogens causing the Verticillium wilt of potato and selection of fungicides in laboratory. Journal of Xinjiang Agricultural University, 37, $218-222$.

Wilhelm, S., \& Taylor, J. B. (1965). Control of Verticillium wilt of olive through natural recovery and resistance. Phytopathology, 55, 310-316.

Wu, F. Z., Liu, B., \& Zhou, X. G. (2010). Effects of root exudates of watermelon cultivars differing in resistance of Fusarium wilt on the growth and development of Fusarium oxysporum f.sp. niveum. Allelopathy Journal, 25(2), 403-414.

Yildiz, M., Yildiz, F., \& Erten, L. (2020). Duyarlı zeytin çeşitlerinin dayanıklı anaç ve çeşitler üzerine aşılanarak zeytinde Verticillium solgunluğunun önlenmesi üzerinde araştırmalar. The Journal of Turkish Phytopathology, 49(1), 19-24.

Zhou, B. L., Chen, Z. X., Du, L., Xie, Y. H., Zhang, Q., \& Ye, X. L. (2011). Allelopathy of root exudates from different resistant eggplants to Verticillium dahliae and the identification of allelochemicals. African Journal of Biotechnology, 10(42), 8284-8290. 